\title{
ЗАЩИТА ПЕРСИКА ОТ ЧЕШУЕКРЫЛЫХ ВРЕДИТЕЛЕЙ
}

\author{
Юдицкая И.В. \\ Мелитопольская опытная станщия садоводства имени М.Ф. Сидоренко ИС НААН, \\ 2. Мелитополь, Украина, e-mail: i.uditskaia@ukr.net
}

\begin{abstract}
The results of the research of efficiency of use of biological preparations against dominant lepidopteran pests in peach plantations in the conditions of the Southern Steppe of Ukraine are presented. It was found that the use of biological preparations reduced the damage of shoots by caterpillars of lepidopteran pests by 2.3-6.1 times, to fruits - by 1.7-3.7 times compared to the control variant.
\end{abstract}

Keywords: peach, pests, Grapholitha molesta, Anarsia lineatella, harmfulness

\section{Введение}

Анализируя большое разнообразие видов вредных насекомых во всех зонах выращивания персика, следует отметить, что самым многочисленным является отряд чешуекрылых или бабочек Lepidoptera [1].

Наиболее опасными видами в насаждениях персика из вышеуказанного ряда являются восточная плодожорка (Grapholitha molesta Busck.), в меньшей степени фруктовая полосатая моль (Anarsia lineatella Zell.).

В Украине восточная плодожорка впервые была зафиксирована в персиковых насаждениях в четырех районах Закарпатской области (1966 г.). В следующем году бабочки вида фиксировались уже на юге (г. Рени и г. Измаил Одесской области). Через 8 лет восточная плодожорка наблюдалась в многолетних насаждениях 12-ти областей республики. Имаго фитофага было отмечено даже в тех областях, где нет насаждений персиков [2, 3].

Фруктовую полосатую моль было впервые обнаружено в окрестностях г. Мелитополя исследователем С.А. Мокржецкий в 1902 году. Вскоре вредитель быстро распространился и на юг. В настоящее время фруктовая полосатая моль вредит насаждениям в Молдавии, Средней Азии, Казахстане, некоторых областях России [4, $5]$.

Гусеницы вышеуказанных вредителей выгрызают сердцевины однолетних неодревесневших побегов, в результате чего они увядают. При сильном повреждении вредителями дерево становится ветвистым, вследствие разрастания боковых побегов. Гусеницы летних поколений повреждают плоды, питаясь мякотью, а иногда проникают внутрь еще не затвердевшей косточки. Таким образом, данные виды являются основными карпофагами в насаждениях персика и приводят к снижению качества плодов, а также потенциальным потерям урожая, достигающим 80-90\% [2, 4].

Контроль численности чешуекрылых вредителей в насаждениях персика достигается за счет применением химических инсектицидов в критические периоды развития вида. Сегодня, для регулирования численности вредителей, в том числе и чешуекрылых, в многолетних насаждениях рядом с химическим методом широко применяется и биологический. Использование биологических средств защиты растений - один из основных элементов современных технологий фитосанитарной оптимизации агроценозов [6, 7]. Поэтому, актуальным является исследование по изучению эффективности биологических препаратов, поскольку плоды персика используются преимущественно в свежем виде. 


\section{Материалы и методы}

Цель исследований заключалась в изучении технической эффективности биопрепаратов против восточной плодожорки и фруктовой полосатой моли для усовершенствования системы защиты персика от доминантных чешуекрылых вредителей.

Изучение технической эффективности биопрепаратов проводились в течение 2018-2019 гг. на сортах персика Редхавен и Золотая Москва среднего и позднего сроков созревания соответственно. Схема опыта включала: контроль (без обработки), биопрепараты Лепидоцид, в.р. 10,0 л/га, Гаупсин, р. в двух нормах расхода 4,0 и 6,0 л/га и Скарадо-М, p. 3,0 и 5,0 л/га. Опрыскивание проводились в период массового лета начала отрождения гусениц восточной плодожорки каждого поколения.

\section{Результаты и обсуждение}

В условиях Южной Степи Украины у вредителя персика - восточной плодожорки за год происходит развитие перезимовавшей генерации и трех летних поколений. Фруктовая полосатая моль за сезон развивается в двух поколениях, часть популяции имеет третью генерацию.

По результатам исследований выявлено, что повреждения побегов персика гусеницами восточной плодожорки при использовании всех биопрепаратов составили на сортах Редхавен и Золотая Москва 1,0-2,4\%, фруктовой полосатой моли - 0,6-1,5\%. В контрольном варианте повреждения побегов гусеницами вышеуказанных видов на двух сортах были на уровне 5,5-5,9\% и 3,5-3,7\%. При этом самая высокая техническая эффективность против чешуекрылых фитофагов отмечалась при использовании биологического препарата Скарадо-М, с нормой расхода 5,0 л/га - 81,8-83,8\%. При уменьшении нормы расхода (3,0 л/га) препарат снижал свою эффективность на 4,4$10,4 \%$.

Техническая эффективность при применении биопрепарата Лепидоцид, 10,0 л/га против восточной плодожорки и фруктовой полосатой моли составляла 57,1-67,3\%.

При обработках насаждений персика с использованием биопрепарата Гаупсин с нормой 4,0 л/га повреждения побегов гусеницами фитофагов находилось практически на уровне препарата Лепидоцид. На сортах Редхавен, Золотая Москва составляли против восточной плодожорки - 2,0-2,4 \%, фруктовой полосатой моли - 1,2-1,5\%. Техническая эффективность препарата Гаупсин в большей норме $(6,0$ л/га) против чешуекрылых вредителей персика в среднем по сортам достигала $65,7-75,7 \%$, а поврежденность побегов - не превышала $1,8 \%$.

Уровень повреждения плодов персика восточной плодожоркой и фруктовой полосатой молью в контрольном варианте составлял соответственно 14,5-16,7\% и 9,511,4\%. Наилучше себя проявил против повреждения плодов персика вышеуказанными фитофагами биопрепарат Скарадо-М, 5,0 л/га. Степень повреждения плодов вредителями в этом варианте на двух сортах не превышала 3,8\%, а техническая эффективность достигала 77,3\%. Уменьшение нормы расхода вышеуказанного препарата до 3,0 л/га ухудшало его эффективность против чешуекрылых фитофагов на $5,7-13,8 \%$.

Использование биопрепаратов Гаупсин (6,0 л/га) и Лепидоцид (10,0 л/га) уменьшило повреждения плодов персика чешуекрылыми вредителями до уровня 3,9$7,1 \%$.

Повреждения плодов персика двух исследуемых сортов, как восточной плодожоркой, так и фруктовой полосатой молью, в варианте с применением 
биопрепарата Гаупсин (4,0 л/га) было самым высоким 5,5-7,7\%. Его техническая эффективность оставалась достаточно низкой 42,1-56,6\%.

\section{Выводы}

Использование биопрепаратов обеспечили уменьшение повреждения побегов гусеницами чешуекрылых фитофагов в 2,3-6,2 раза, плодов - в 1,7-4,4 раза в сравнении с контрольным вариантом. Наивысшую техническую эффективность против фитофагов проявил биопрепарат Скарадо-М в норме расхода 5,0 л/га 72,6-83,8\%. Данный показатель при применении биопрепаратов Гаупсин $(6,0$ л/га) и Лепидоцид $(10,0$ л/га) оказался меньше в 1,2-1,5 раза.

\section{Библиография}

1. Шармагий И.Н., Иовлева С.П. Чешуекрылые вредители персика в предгорной зоне Крыма. Научные труды ЮФ НУБиП Украины «КАТУ». Серия: Сельскохозяйственные науки. 2011. Вып. 137. С. 163-170.

2. Омелюта В.П., Чернишов О.В. Східна плодожерка в Україні. Захист рослин. 1996. № 4. C. $14-15$.

3. Клечковський Ю.Е., Трибель С.О. Східна плодожерка: монографія. Одеса, 2005. 89 с. 4. Чепурная В.И., Мялова ЈІ.А. Вредители и болезни персика. Защита растений. 1990. № 3. С. 50-52.

5. Ярышева И.А. Чешуекрылые вредители персиковых насаждений в Краснодарском крае и совершенствование мер борьбы с ними: автореф. дис. на соискателя канд. биол. наук: 06.01.11. Краснодар, 2002. 20 с.

6. Федоренко В.П., Ткаленко А.Н., Конверская В.П. Оптимизация биологический защиты плодовых насаждений от вредителей. Международная научно-практ. конф., Одесса, 8-13 сентября 2008 г. Институт защиты растений УААН. К.: Колобиг, 2008. С. 22-30. 